\title{
Identifying water mass depletion in northern Iraq observed by GRACE
}

\author{
G. Mulder ${ }^{1}$, T. N. Olsthoorn ${ }^{1}$, D. A. M. A. Al-Manmi ${ }^{2}$, E. J. O. Schrama ${ }^{1}$, and E. H. Smidt ${ }^{1}$ \\ ${ }^{1}$ Delft University of Technology, Delft, the Netherlands \\ ${ }^{2}$ University of Sulaimani, Department of Geology, Sulaymaniyah, Iraq
}

Correspondence to: G. Mulder (gert.mulder@gmail.com)

Received: 3 September 2014 - Published in Hydrol. Earth Syst. Sci. Discuss.: 17 October 2014

Revised: 16 February 2015 - Accepted: 27 February 2015 - Published: 24 March 2015

\begin{abstract}
Observations acquired by Gravity Recovery And Climate Experiment (GRACE) mission indicate a mass loss of $146 \pm 6 \mathrm{~mm}$ equivalent water height $(\mathrm{EWH})$ in northern Iraq between 2007 and 2009. These data are used as an independent validation of lake mass variations and a rainfallrunoff model, which is based on local geology and climate conditions. Model inputs are precipitation from Tropical Rainfall Measurement Mission (TRMM) observations, and climatic parameters from Global Land Data Assimilation Systems (GLDAS) model parameters. The model is calibrated with observed river discharge and includes a representation of the karstified aquifers in the region to improve model realism. Lake mass variations were derived from Moderate Resolution Imaging Spectroradiometer (MODIS) in combination with satellite altimetry and some in situ data. Our rainfall-runoff model confirms that northern Iraq suffered a drought between 2007 and 2009 and captures the annual cycle and longer trend of the observed GRACE data. The total mass depletion seen by GRACE between 2007 and 2009 is mainly explained by a lake mass depletion of $75 \pm 3 \mathrm{~mm}$ EWH and a natural groundwater depletion of $39 \pm 8 \mathrm{~mm}$ EWH. Our findings indicate that anthropogenic groundwater extraction has a minor influence in this region, while a decline in lake mass and natural depletion of groundwater play a key role.
\end{abstract}

\section{Introduction}

From 2007 to 2009, northern Iraq suffered a severe drought, with rainfall rates $40 \%$ below normal levels (Trigo et al., 2010; Fadhil, 2011). In the same period, discharge of large springs and rivers decreased substantially and data from the
GRACE satellite mission indicated a permanent loss of water mass in the region (UN-ESCWA and BGR, 2013; Voss et al., 2013). Decrease in rainfall and water availability directly affected the water supply of towns and villages (Michel et al., 2012) and caused a strong decline in crop yields in northern Iraq (Trigo et al., 2010). About 100000 people have left their homes in northern Iraq as a consequence of depleted water sources (McLeman, 2011). From 2009 onwards, rainfall rates have been rising, but are still lower than before the drought period. Moreover, a permanent decrease of rainfall rates in the region is predicted, based on climate models (Gibelin and Déqué, 2003; Giorgi and Lionello, 2008; Mariotti et al., 2008).

Concurrent with decreasing water availability in the region, water demands are fast increasing due to population growth and increase of irrigated agriculture (Altinbilek, 2004; Beaumont, 1998). Especially in Turkey, water demands increase rapidly due to the Southeastern Anatolia Project (GAP), which includes the construction of dams and irrigation schemes in the upstream Tigris catchment. At this moment, about 42000 ha of this irrigation scheme is operational, with 53400 ha under development and another 500000 ha planned in future years (Altinbilek, 1997). Additionally, several dams and irrigation projects are under construction in the Iranian headwaters of the Tigris, which will reduce river flows in northern Iraq permanently (Ali, 2007).

This means that especially northern Iraq has to cope with a permanent decrease of its water resources due to lower rainfall and lower river flows from upstream countries. Because agreements on water between riparian countries are either hardly effective or non-existent, there are no guarantees that Iraq will ever receive as much water as before (UN-ESCWA and BGR, 2013; Al-Manmi, 2009). 
Table 1. Summary of data used in this study

\begin{tabular}{|c|c|c|c|c|c|}
\hline \multirow[t]{2}{*}{ Variable } & \multirow[t]{2}{*}{ Data set } & \multirow[t]{2}{*}{ Product } & \multicolumn{2}{|c|}{ Resolution } & \multirow[t]{2}{*}{ Period } \\
\hline & & & Spatial & Temporal & \\
\hline Water mass variation & GRACE CSR & - & - & $1 \mathrm{mo}$ & 2003-2012 \\
\hline Precipitation & TRMM & 3B42 V7 & $0.25^{\circ} \times 0.25^{\circ}$ & $1 \mathrm{~d}$ & 1999-2012 \\
\hline Precipitation & Data Meteorological department Kurdistan & - & - & $1 \mathrm{~d}$ & 2001-2012 \\
\hline Streamflow & Data Directorate Dukan Dam & - & - & $1 \mathrm{~d}$ & 2001-2012 \\
\hline Temperature & GLDAS & NOAH V2.7 & $0.25^{\circ} \times 0.25^{\circ}$ & $3 \mathrm{~h}$ & 2001-2012 \\
\hline Climatic parameters & GLDAS & NOAH V2.7 & $0.25^{\circ} \times 0.25^{\circ}$ & $3 \mathrm{~h}$ & 2001-2012 \\
\hline Soil moisture desert area & GLDAS & NOAH V2.7 & $0.25^{\circ} \times 0.25^{\circ}$ & $3 \mathrm{~h}$ & 2001-2012 \\
\hline \multirow[t]{2}{*}{ Lake levels } & Envisat & - & - & $35 \mathrm{~d}$ & 2002-2010 \\
\hline & Jason $1 \& 2$ & - & - & $10 \mathrm{~d}$ & 2002-2015 \\
\hline Lake area & MODIS & MOD09Q1 & $250 \times 250 \mathrm{~m}$ & $8 \mathrm{~d}$ & 2002-2012 \\
\hline Lake area & MODIS & MOD09A1 & $500 \times 500 \mathrm{~m}$ & $8 \mathrm{~d}$ & 2002-2012 \\
\hline
\end{tabular}

Several hydrologic studies of the region exist (Chenoweth et al., 2011; Kavvas et al., 2011), but they are generally coarse due to the lack of ground truth and do not yield specific information on hydrology and groundwater storages. Mass observations from GRACE provide a valuable tool to give more insight into the terrestrial water storages and are widely used as a validation of global hydrologic models like GLDAS, WaterGAP Global Hydrology Model (WGHM) and the Organising Carbon and Hydrology in Dynamic Ecosystems (ORCHIDEE) (Voss et al., 2013; Werth et al., 2009; Awange et al., 2011; Hinderer et al., 2006; Schmidt et al., 2008; Ngo-Duc et al., 2007). For the Euphrates and Tigris region, a comparison between GRACE and the GLDAS model was made by Voss et al. (2013), which showed a large difference in both yearly and long-term mass variations. This could indicate that anthropogenic groundwater extraction is a main cause of water depletion in the region, but the inability of the GLDAS model to capture yearly water mass variations makes the outcomes doubtful. Moreover, the GLDAS model does not contain a groundwater reservoir, which is important to track natural groundwater variations.

In this study, independent mass variations obtained from GRACE data are compared with water mass variation from lakes/reservoirs and a newly developed rainfall-runoff model, to show that these are likely the main causes of water mass depletion in the region. GRACE mass variation is derived using a mascon approach from Schrama et al. (2014) and the rainfall-runoff model is based on the general hydrology and geology of the region using the topo flex approach from Savenije (2010) and Fenicia et al. (2011). Forcing data for this model is based on climatic parameters from the GLDAS model; daily rainfall from TRMM and local rainfall stations. Calibration of the model is done using local discharge measurements. MODIS surface reflectance data were used in combination with altimetry data from the Environmental Satellite (Envisat), Jason 1\&2 and GEOSAT FollowOn (GFO) satellite missions (Crétaux et al., 2011) to find lake mass variations. Local hydrologic and geologic data were ob- tained during fieldwork in co-operation with local water experts. In situ data include discharge data of one of the Tigris River tributaries (Directorate Dukan Dam, unpublished data) and rainfall data from four stations in the region (Meteorological department Kurdistan, unpublished data).

The following modelling steps will be used to compare GRACE data with water mass variations from lakes/reservoirs and the rainfall-runoff model: firstly, the total mass variation from an extended study area is derived from GRACE using a mascon approach. Secondly, the surface water mass is calculated for the same area and extracted from GRACE data, to obtain an approximate soil moisture and groundwater mass variation. Thirdly, the study area is reduced to northern Iraq only, using soil moisture data from GLDAS. Finally, the natural variation in soil moisture and groundwater mass for northern Iraq is calculated using a newly developed rainfall-runoff model.

\section{Study area}

Most of northern Iraq is part of the upstream catchment of the Tigris River, which originates in Turkey and flows southwards to the Persian gulf. The total yearly flow of the Tigris at Baghdad is about $50 \mathrm{~km}^{3} \mathrm{yr}^{-1}$, of which half originates from upstream catchments in Turkey and half from tributaries in northern Iraq (Brooks, 1997; Altinbilek, 2004). Figure 1 gives an elevation map of the total study area, which includes five main tributaries of the Tigris River, of which four have headwaters in Turkey or Iran. Figure 1 also presents a map of the mean yearly rainfall rates between 2002 and 2012, based on TRMM 3B42 (V7) data (Huffman et al., 2007). This map illustrates the large climatic variations in this area. While the southwestern part of the catchment has a desert climate with rainfall rates of about $200 \mathrm{~mm} \mathrm{yr}^{-1}$, the northeastern part consists of a mountain range with a considerably colder climate and rainfall rates up to $1000 \mathrm{~mm} \mathrm{yr}^{-1}$. The mountainous region in the north and northeast of the catch- 

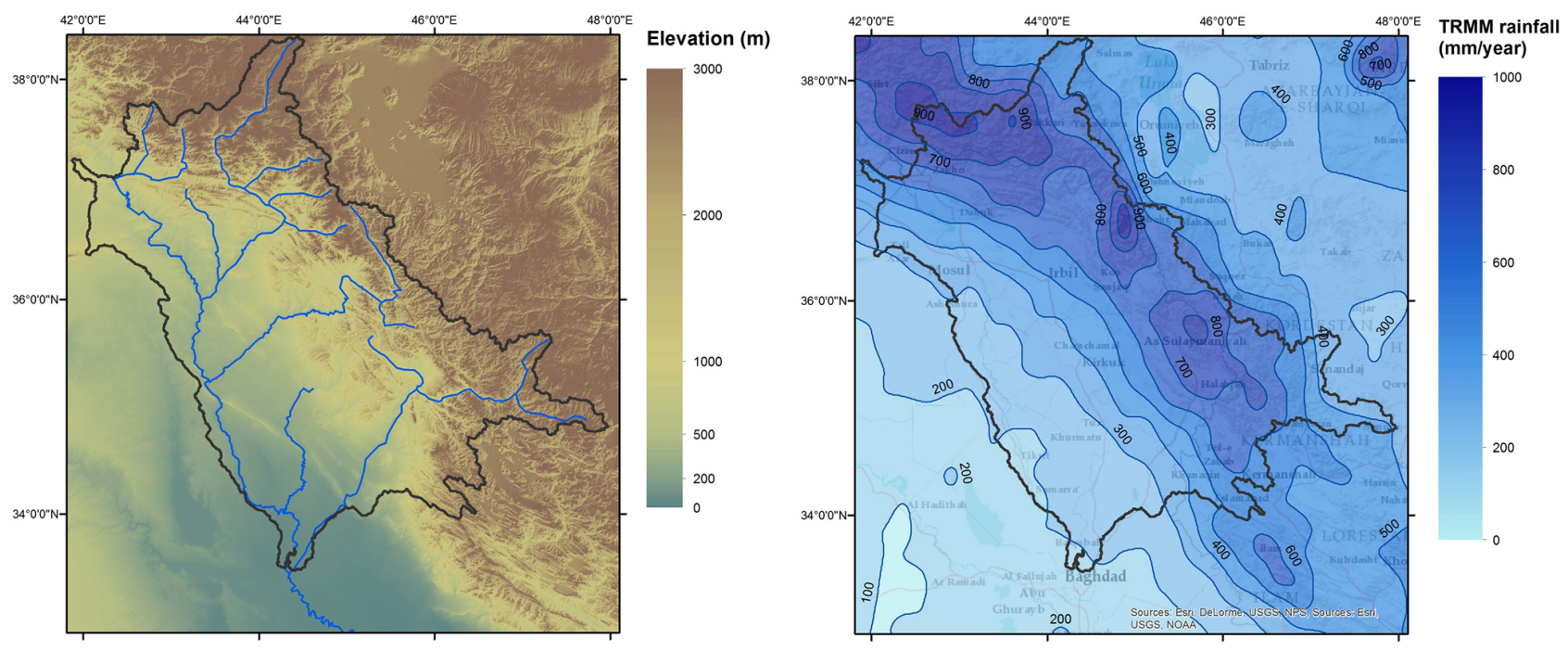

Figure 1. (left) Topographic map of northern Iraq based on SRTM data and (right) the average yearly rainfall between 2002 and 2012 $\left(\mathrm{mm} \mathrm{yr}^{-1}\right)$ based on TRMM data.

ment is the main source of water of the Tigris River, while the arid areas in the southwest are totally dependent on upstream river water (Beaumont, 1998; Brooks, 1997). Beside spatial differences in climates, there are also large seasonal and yearly variations in rainfall and temperatures. Almost all rain falls during the winter period, between November and March, and mean rainfall rates can drop by $50 \%$ in dry years.

To ensure water supply in the region during dry periods, many reservoirs were built from the 1950s onwards and several are currently under construction. northern Iraq includes the lakes of Mosul, Dukan, Darbandikhan, Adhaim and Hamrin, which all show a water mass decline during the 2007-2009 drought. But also water mass decline from lakes close to our study area, like Lake Tharthar, Habbaniyah, Qadisiyah, Urmia and Razzaza, are considered in this research (Fig. 2).

\section{Methods}

\subsection{GRACE mass variation calculations}

During the last years, several methods have been developed to calculate mass change based on GRACE data, e.g. Swenson and Wahr (2006) and Schrama and Wouters (2011). Most methods comprise different processing steps, mainly to reduce noise, apply geophysical corrections, add consistency and improve the ability of GRACE to see spatial details. This study uses a mascon approach, based on circular mascons with a radius of approximately one degree, which are evenly distributed over the Earth's surface (Schrama et al., 2014). This method is based of GRACE level-2 data from the Center of Space Research (CSR) and includes modifications for the gravitational flattening term $\mathrm{C} 20$ from satellite laser rang- ing. Furthermore, the method also considers degree- 1 terms associated with geo-centre motions as a result of geophysical loading phenomena. The used GRACE method is not a spatial averaging kernel method; instead, to obtain equivalent water levels over a region one has to add up the signal from the individual mascons. The signal at these mascons is obtained via a global inversion method. The advantage of this approach is that resulting equivalent water height $(\mathrm{EWH})$ values are part of a standard GRACE product and will be consistent with other regional solutions worldwide. The disadvantage is that we have to adapt our study area to the given mascons. We are thus not able to use approaches like that of Krogh et al. (2010), which adapt the mascons to the geometry of the studied basin. However, a simple test where adjacent mascons were added to our study area, showed that small changes in study area do not have significant effects on the resulting GRACE values. Also, comparison between our method and other common methods by Shepherd et al. (2012) showed that differences are generally small.

To calculate water mass decline from GRACE data, an extended study area is used. Figure 2 shows the used area and mascon coverage for the GRACE mass calculations. This area is about $26010^{3} \mathrm{~km}^{2}$ and includes a large part of the catchment of Lake Urmia $\left( \pm 45 \times 10^{3} \mathrm{~km}^{2}\right)$ and a part of the desert to the south-west of North Iraq $\left( \pm 95 \times 10^{3} \mathrm{~km}^{2}\right)$. The desert area was added because we want to make sure that the mass decline from Lake Tharthar (Fig. 2) is fully captured by our GRACE mass calculation and can be corrected for later on. This lake showed a decline in water mass of about $48 \mathrm{~mm}$ EWH for the extended study area during the 20072009 drought, which is more than $50 \%$ of the total lake mass decline. Other lakes like Lake Razzaza and Lake Urmia are still close to the border, but these lakes showed much less wa- 

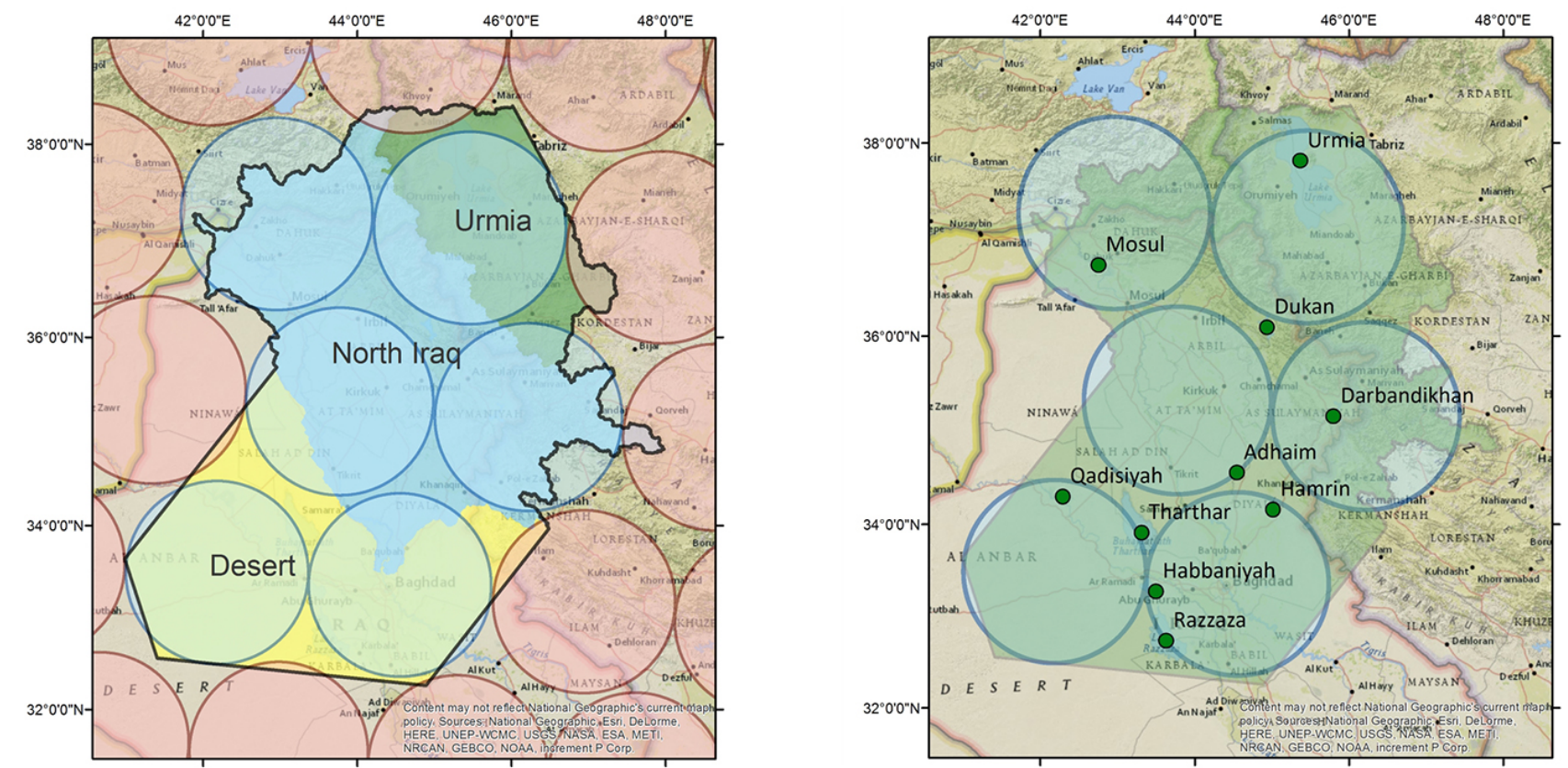

Figure 2. (left) Mascon coverage area for GRACE calculations. In the southwest the included desert area and in the northeast the included Urmia catchment. The blue circles show the coverage of the mascons used and the red circles mascons outside the study area. (right) Map of the total study area including the used mascons and lakes.

ter mass depletion between 2007-2009 (Table 2). The presence of these lakes close to the border of our study area induces mass leakage outside our study area (Longuevergne et al., 2013), which is corrected for as explained in Sect. 3.2.

To compare the total water mass variation of the rainfallrunoff of northern Iraq with GRACE, the derived GRACE mass was corrected for soil moisture and groundwater mass variation of the extended area in the southwestern desert. Groundwater pumping in these areas is generally small due to high salt content of the groundwater or deep groundwater tables (Krásný et al., 2006) and is estimated around 30$35 \times 10^{-3} \mathrm{~km}^{3} \mathrm{yr}^{-1}$ (UN-ESCWA and BGR, 2013). Because recharge and discharge rates of the aquifers are also very low in this area, we do not expect significant groundwater variations in this region. Therefore, we assumed that the soil moisture profile from GLDAS (Rodell et al., 2004) can be used as a measure for the total water mass variation in the area. The new GRACE values for northern Iraq then become

$H=\frac{H_{\mathrm{t}} A_{\mathrm{t}}-G_{\mathrm{d}} A_{\mathrm{d}}}{A_{\mathrm{t}}-A_{\mathrm{d}}}$,

where $H$ is the equivalent water height, $A$ is the total area and $G$ is the soil moisture variation in water depth from the GLDAS model. Subscripts $t$ and d indicate total and desert areas.

This correction assumes a pristine area, which is not true for the irrigated areas around Baghdad in Central Iraq. This likely causes an underestimation of the yearly water mass variation due to the growing season of the crops in this re- gion. However, water mass decline due to anthropogenic groundwater extraction is small because of the high salt content of groundwater in this region (Krásný et al., 2006).

Because the influence of groundwater variation is large in the catchment of Lake Urmia (Fig. 2), the correction used for the Desert area cannot be applied here (Tourian et al., 2015). Instead, the hydrology of the region is comparable with northern Iraq. Therefore, the water mass variation in mm EWH from the catchment of Lake Urmia are neglected and assumed to be the same as in northern Iraq. This introduces an error in the model on a small timescale due to local rainfall events, but on a longer timescale these errors will be minor due the similarities between the regions.

\subsection{Derivation of lake mass}

The total lake mass variations play an important role in the water balance of the Tigris region (Voss et al., 2013; Longuevergne et al., 2013). Figure 2 gives an oversight of the important lakes in the region. To obtain total lake mass contributions in our study area, time series of both lake level and lake area were calculated. The lake levels are derived from satellite altimetry by Crétaux et al. (2011) and USDA/FAS (2013), which includes data from the Envisat, Jason 1\&2 and GFO satellite missions. Area calculations were based on MODIS satellite data to detect water areas, combined with digital elevation maps (DEMs) from the Shuttle Radar Topography Mission (SRTM) to distinguish different water bodies. The actual method uses a $250 \times 250 \mathrm{~m}$ grid and con- 


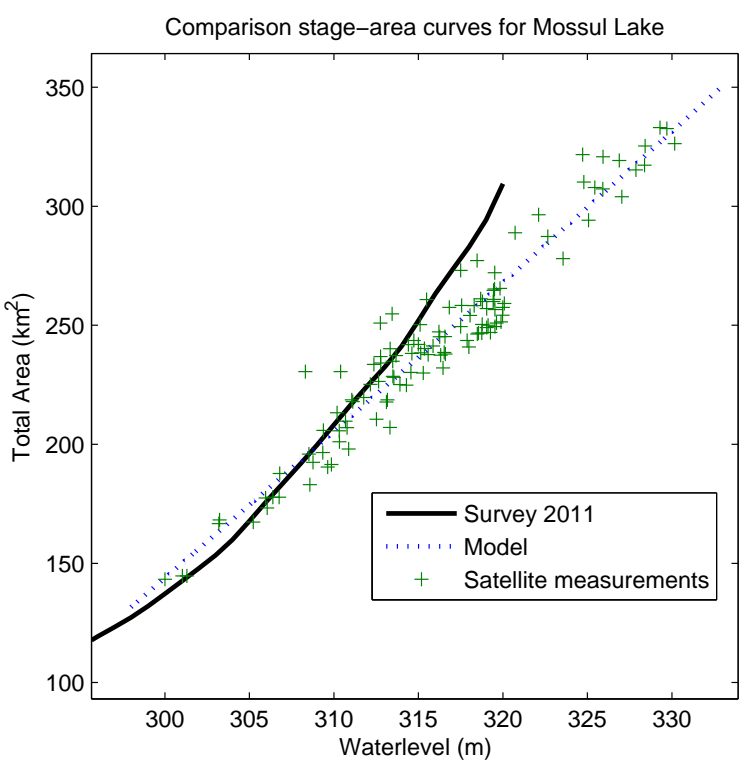

Figure 3. Linear regression stage-area curve for lake Mosul. The curve is compared with a survey in 2011 using sonar by Issa et al. (2013).

sists of three steps: first, the possible extent of the lake was calculated from the DEM using a minimum and maximum elevation. Second, the larger lake areas were selected using MODIS reflectance band 5 (1240 nm, $500 \mathrm{~m}$ resolution). Finally, the exact lake borders were defined using MODIS reflectance band $2(858 \mathrm{~nm}, 250 \mathrm{~m}$ resolution).

From the lake level and lake area time series, stagearea curves were created using linear or cubic regression. In Fig. 3, a comparison is given of the derived stage-area curve from our model and a survey of Lake Mosul using sonar by Issa et al. (2013). To decide whether a cubic regression gives a significant improvement, the $F$ test was used for a $95 \%$ interval. Total volume change over time was then derived from the stage-volume curve, which is the integrated stage-area curve. Table 2 gives the derived water mass decline between 2007 and 2009 of the main lakes in the region. This water mass decline is derived by subtracting the average water mass in 2009 from the average water mass in 2006.

Uncertainties in water mass calculations from lakes are derived from estimated errors in water level measurements given by Crétaux et al. (2011) and USDA/FAS (2013). The total error is given by

$\sigma^{t}=\sqrt{\frac{\sum_{i=1}^{n}\left(\sigma_{i}^{t} A_{i}^{t}\right)^{2}}{n}}$

where $\sigma_{i}^{t}$ is the estimated standard deviation of the lake water level from lake $i$ at time $t, n$ is the number of lakes and $A_{i}^{t}$ is the lake area at the same moment.

Another source of uncertainty are the errors in lake area calculations, but these are generally small and are difficult to
Table 2. Oversight of water mass decline of lakes within the extended study area in $\mathrm{km}^{3}$ and $\mathrm{mm}$ EWH. Note that the mass decline of Lake Urmia and Lake Razzaza is part of a more gradual mass decline, while the water mass decline of other lakes mainly occurred during the 2007-2009 drought due to lake management.

\begin{tabular}{lrr}
\hline & \multicolumn{2}{c}{ Mass decline } \\
Lake & \multicolumn{1}{c}{$\begin{array}{c}\text { km } \\
\text { (3) }\end{array}$} & $\mathrm{mm} \mathrm{EWH}$ \\
\hline Tharthar & $12.45 \pm 0.04$ & $47.9 \pm 0.14$ \\
Habbaniyah & $0.66 \pm 0.04$ & $2.53 \pm 0.15$ \\
Razzaza & $1.18 \pm 0.10$ & $4.57 \pm 0.39$ \\
Hamrin & $0.55 \pm 0.02$ & $2.11 \pm 0.08$ \\
Adhaim & $0.19 \pm 0.10$ & $0.73 \pm 0.38$ \\
Dukan & $0.94 \pm 0.06$ & $3.60 \pm 0.21$ \\
Qadisiyah & $5.08 \pm 0.05$ & $19.5 \pm 0.2$ \\
Urmia & $4.06 \pm 0.14$ & $15.6 \pm 0.6$ \\
Mosul & $0.97 \pm 0.06$ & $3.74 \pm 0.22$ \\
\hline
\end{tabular}

quantify. For example, the difference in lake size from Lake Mosul and the derived values from Issa et al. (2013) (Fig. 3) are about $10 \mathrm{~km}^{2}$ but it only causes significant errors in the stage-volume curve for high water levels. Additionally, the relative error for larger lakes is much smaller because the ratio between lake shore length and lake area becomes smaller with increasing lake size.

To give an approximation of mass leakage from lakes in our study area results from Longuevergne et al. (2013) are used. This led to a correction for Lake Razzaza of 0.65 and a correction for Lake Urmia of 0.6 , because these lakes are located close to the border and far from the centre of the study area. Corrections for other lakes were not significant and were therefore omitted.

\subsection{Rainfall-runoff model}

In this study, a rainfall-runoff model was used based on the topo flex approach as proposed by Savenije (2010) and Fenicia et al. (2011) and a simplified snow routine based on Lindström et al. (1997). This resulted in a semi-distributed model structure, based on the geology and topography of the five main tributaries of the Tigris River in northern Iraq (Fig. 4). Forcing parameters of the rainfall-runoff model are calibrated daily precipitation data from TRMM (Huffman et al., 2007), daily temperature values from GLDAS and daily reference evaporation derived from GLDAS climatic parameters (Rodell et al., 2004; Allen et al., 1998). TRMM data were bias-corrected by linear regression with monthly precipitation from four gauging stations in Sulaymaniyah, Dukan, Darbandikhan and Penjwen (Meteorological Department of Kurdistan, unpublished data).

The rainfall-runoff model is identical for all five tributaries, and is based on three geologic zones in accordance with geologic maps of Stevanovic and Iurkiewicz (2008). The three zones are: 

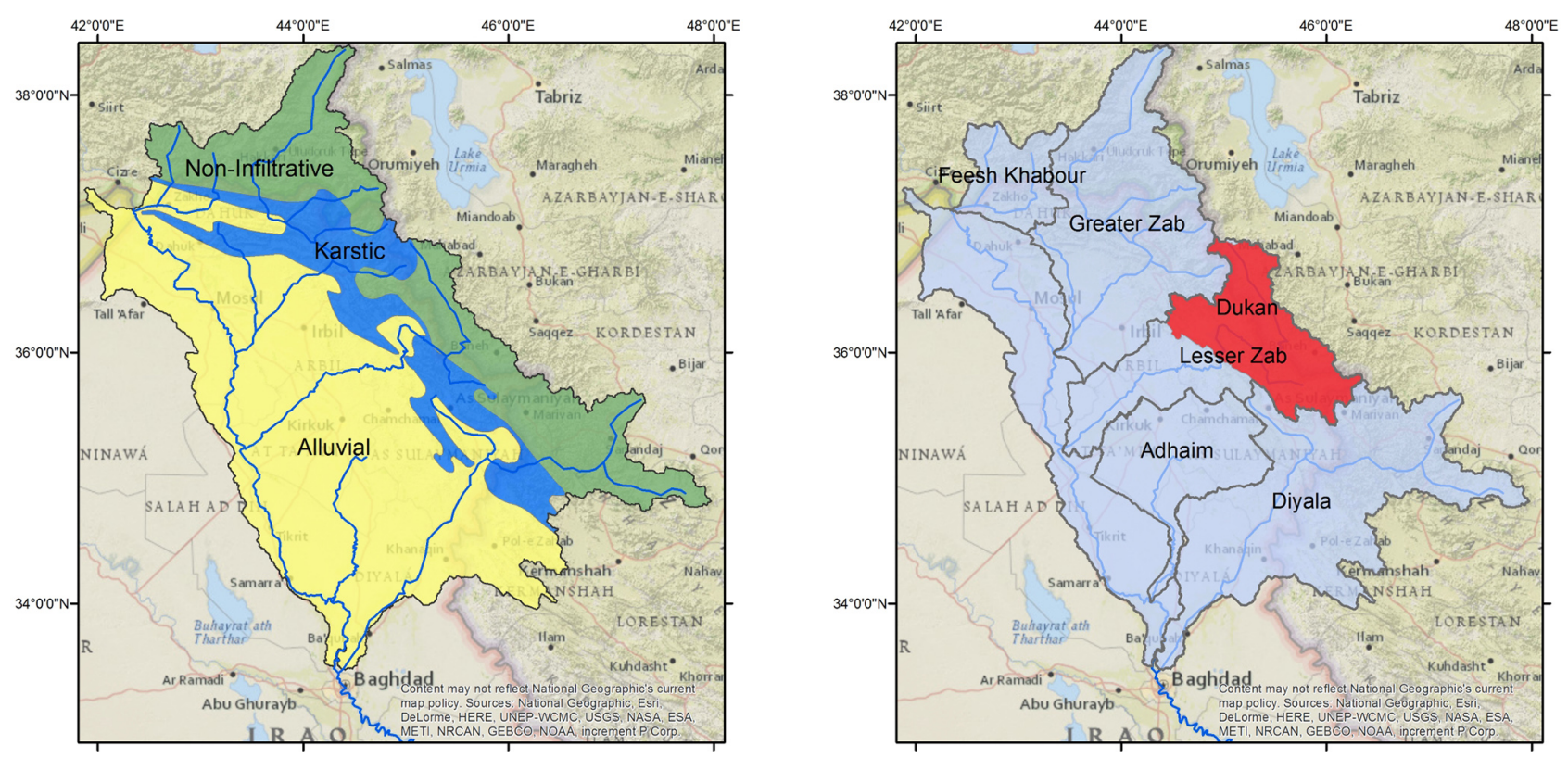

Figure 4. (left) Approximate division of northern Iraq into three geologic zones, mainly based on Stevanovic and Iurkiewicz (2008). (right) Boundaries of main tributaries of the Tigris in northern Iraq. The Dukan catchment, which is the upper part of the Lesser Zab catchment, is indicated in red. Calibration on streamflow is based on measurements from the Dukan area and calculation of water mass for the whole of northern Iraq is based on all catchments.

1. Infiltrative or karstified zone: about one-third of the surface area of the mountainous zone consists of karstified limestone and is, therefore, highly infiltrative. These limestones have infiltration rates of more than $50 \%$ and transmissivities ranging from 9 to $8000 \mathrm{~m}^{2} \mathrm{day}^{-1}$ (Krásný et al., 2006).

2. Non-infiltrative zone: this zone consists of the other mountainous areas, which are characterised by fast runoff due to shallow soil layers, steep slopes and impermeable underlying formations.

3. Alluvial zone: most of the soils in the dry southwestern part consist of clay and silt sediments. In this region flash floods are common during the scarce rainfall events.

For all five tributaries of the Tigris River in northern Iraq and the remaining area close to the Tigris River the same model setup is used, with the total areas of the three geologic zones as the only difference. For example, the flow regime of the Adhaim River is governed by the alluvial part of the model, while the Greater Zab is mainly fed by water from the infiltrative and non-infiltrative zones.

Figure 5 gives a detailed oversight of the model reservoirs and parameters. The snow routine and unsaturated reservoirs are modelled in a distributed way, using the $0.25^{\circ}$ grid from TRMM as a basis. When grid cells are part of two or more different basins or geologic zones the cell is split up into different parts, which contribute to their respective zones or catchments. Parameter values of different grid cells were kept the same within the geologic zones, while input precipitation from TRMM and climatic values from GLDAS were separately assigned to each cell. From the unsaturated zone, water is either routed via the fast runoff or groundwater reservoir to the river. A lag function was added to the model to simulate the routing of water through streams and rivers to the catchment outflow. The fast runoff and deep groundwater reservoirs of the infiltrative and non-infiltrative zones were combined, because the topography and top soils are comparable and share the same underlying aquifers (Krásný et al., 2006). A total of 18 parameters were used in the model, which were restricted to minimum and maximum bounds during calibration to prevent equifinality and ensure realism of the model. In particular, the parameters for the karstified/infiltrative groundwater reservoir have a strong influence on the modelled water mass variations. The parameter value for this reservoir is based on the recession curves of spring discharges which emerge from the karstified aquifer in northern Iraq. Generally, the discharge from the karstic aquifers in northern Iraq can be split up into two components (Stevanovic and Iurkiewicz, 2008; Ali and Stevanovic, 2010). The first component is a rapid discharge within a month after major rain events, which is related to channels and large fractures in the limestone aquifer. The second component is a much slower discharge with a stable recession coefficient during the whole dry season. This coefficient is about 0.004 per day on average, based on discharge time series of several large springs in the region (Ali and Stevanovic, 2010; Ali 


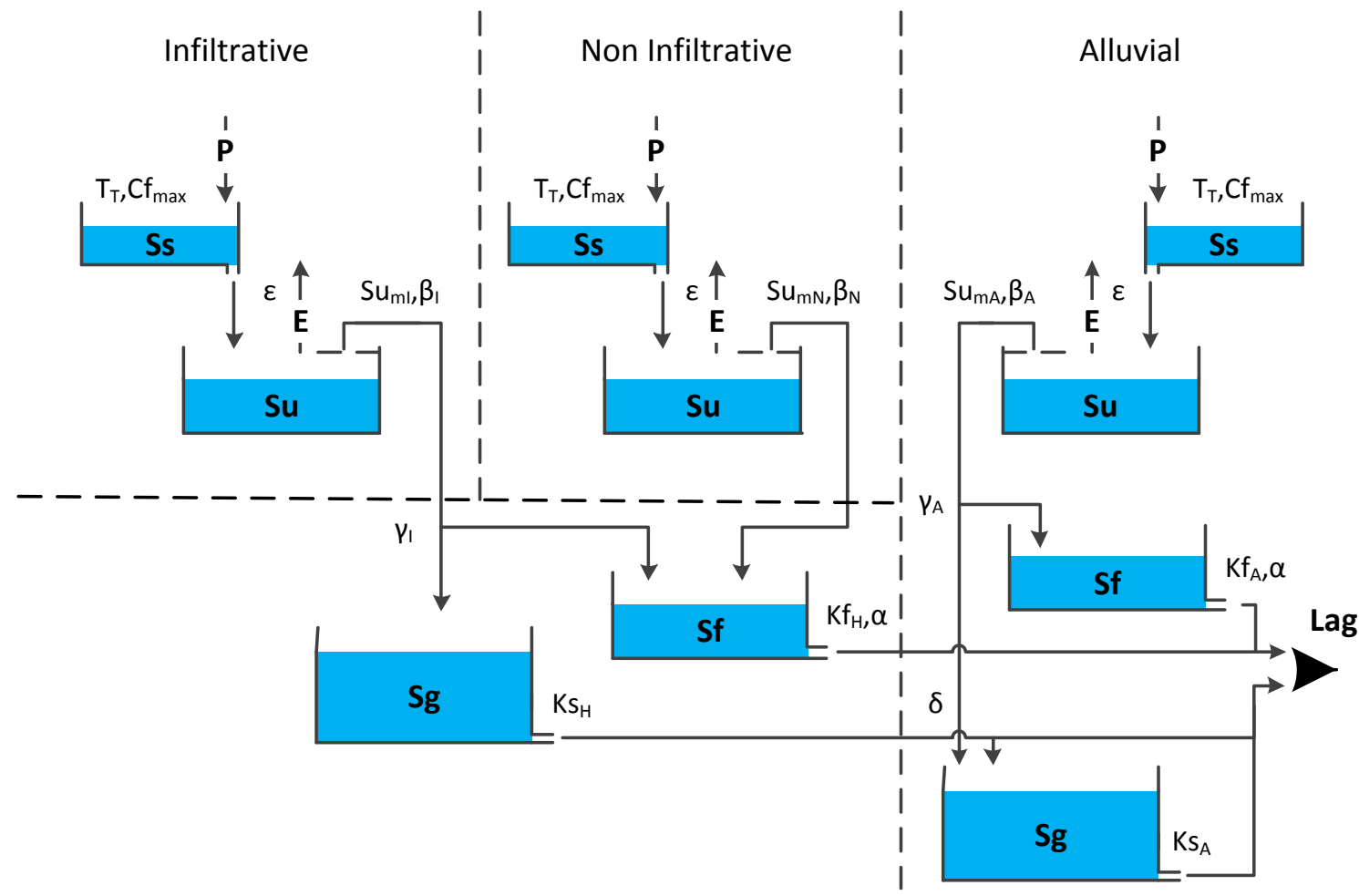

Figure 5. Setup of the rainfall-runoff model based on the three main land classes in northern Iraq. The upper three reservoirs (Ss) represent the snow accumulation in the basin based in precipitation and temperature. The second layer of three reservoirs (Su) represent the water storage in the unsaturated zone and routes runoff to the fast runoff (Sf) and groundwater (Sg) reservoirs. The third layer of two reservoirs (Sf) represent the water storage related to fast runoff processes, which consist of overland flow and interflow. The two bottom reservoirs represent the groundwater storage, which is the main focus in this study. The water fluxes, indicated with arrows, are calculated based on reservoir levels and model parameters.

et al., 2009a, b). The first component is covered by the fast reservoir in our hydrologic model, while the second component is modelled as a slow groundwater reservoir. The bounds of the storage and infiltration rates in the unsaturated reservoirs were based on fieldwork and personal communication with local hydrologists.

\subsection{Model calibration}

In literature generally two methods are used to integrate GRACE mass into the calibration and validation process. Either GRACE information is used to inform the model as a calibration parameter like in Werth et al. (2009), or to validate the model like in Syed et al. (2008). In our case it would be best to use the GRACE data to inform the model, because we want to show that a hydrologic model is able to mimic the mass depletion observed by GRACE. However, during the lifespan of the GRACE satellite only one drought like in 2007-2009 occurred in our region, which makes it impossible to use a separate calibration and validation period. Therefore, we have chosen to use the GRACE data only as a validation of the model, but include also the results for the case that GRACE was used to inform the model. This ap- proach shows that the resulting water depletion will increase due to the inclusion of GRACE data, although this only has relatively small impact on model behaviour.

The primary source for model calibration is river discharge of the Lesser Zab (Directorate Dukan Dam, unpublished data) at the inflow of Lake Dukan (see Fig. 4). The most convenient data to calibrate the model on would be the discharge from the total study area at Baghdad, but these data were not available for us. Additionally, the discharge at this point is not suitable for rainfall-runoff modelling, because it is strongly influenced by the operation of upstream dams and reservoirs. Therefore, the performance of the model was first evaluated for the upstream are of Lake Dukan and expanded to the whole of northern Iraq, to allow comparison with GRACE. This expansion is possible due to the geologic similarities in the region, which are explained in Sect. 3.3.

Model calibration was done using a Monte Carlo simulation with randomly chosen parameter values for every model run, within given parameter bounds. Total discharge for the Dukan area was evaluated by the Nash-Sutcliffe efficiency (NS) for medium and high flows and by the log Nash- 
Sutcliffe efficiency $(\log$ NS) c:

$$
\begin{gathered}
\mathrm{NS}_{Q}=1-\frac{\sum_{t=1}^{T}\left(Q_{\mathrm{o}}^{t}-Q_{\mathrm{m}}^{t}\right)^{2}}{\sum_{t=1}^{T}\left(Q_{\mathrm{o}}^{t}-\overline{Q_{\mathrm{o}}}\right)^{2}} \\
\log \mathrm{NS}_{Q}=1-\frac{\sum_{t=1}^{T}\left(\log \left(Q_{\mathrm{o}}^{t}\right)-\log \left(Q_{\mathrm{m}}^{t}\right)\right)^{2}}{\sum_{t=1}^{T}\left(\log \left(Q_{\mathrm{o}}^{t}\right)-\log \left(\overline{Q_{\mathrm{o}}}\right)\right)^{2}},
\end{gathered}
$$

where $Q_{\mathrm{o}}$ represents the observed daily discharges, $\overline{Q_{\mathrm{o}}}$ the average observed daily discharge and $Q_{\mathrm{m}}$ the modelled daily discharge. In the case that GRACE mass was also used as a calibration parameter, model mass performance was evaluated using the Nash-Sutcliffe efficiency for water mass variation:

$$
\mathrm{NS}_{M}=1-\frac{\sum_{t=1}^{T}\left(M_{\mathrm{o}}^{t}-M_{\mathrm{m}}^{t}\right)^{2}}{\sum_{t=1}^{T}\left(M_{\mathrm{o}}^{t}-\overline{M_{\mathrm{o}}}\right)^{2}},
$$

where $M_{\mathrm{O}}$ represents the observed mass variations from GRACE, $\overline{M_{\mathrm{o}}}$ the average observed GRACE mass and $M_{\mathrm{m}}$ the modelled mass variation from lakes and the rainfall-runoff model. Figure 6 gives the Pareto front for the average $\mathrm{NS}_{Q}$ and $\log \mathrm{NS}_{Q}$ of the river discharge. In the same figure the $\mathrm{NS}_{Q}$ and ${ }_{\log } \mathrm{NS}_{Q}$ values are given of the additional models from the Pareto front if $\mathrm{NS}_{M}$ were to be added as a third objective parameter. The presented optimal solution was chosen based on the following condition:

$$
\max \left(\mathrm{NS}_{Q}+{ }_{\log } \mathrm{NS}_{Q}\right) \text {. }
$$

In the next section, the model ensemble of the models from the Pareto front are given as an uncertainty band, beside the optimal solution.

\section{Results and discussion}

\subsection{GRACE}

Figure 7 shows the resulting GRACE values in terms of equivalent water height, with an estimated $95 \%$ confidence band of $20 \mathrm{~mm}$ (Schrama et al., 2007). Water mass depletion between 2007 and 2009 is $146 \pm 6 \mathrm{~mm}$ EWH. These values are based on the average GRACE value before and after the drought, which is more or less constant. Yearly variation is $286 \pm 24 \mathrm{~mm}$ based on the yearly minimum and maximum values between 2003 and 2011. In the lower graph of Fig. 7, the average monthly rainfall is given for the same period to show the relation between GRACE values and rainfall. The periods with more than average rainfall generally coincide

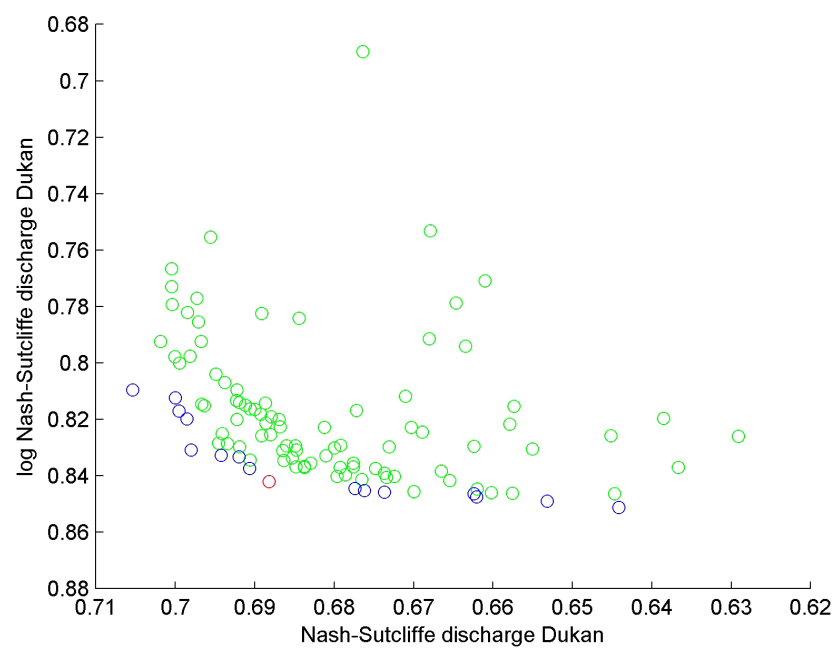

Figure 6. Pareto front for the performance indicators for river flow at the inflow of Lake Dukan. The NS model performance is given on the $y$ axis and the $\log$ NS model performance on the $x$ axis. The blue dots represent the models on the Pareto front and the red dot the chosen optimal solution. The green dots represent the extra points on the three-dimensional Pareto front if the NS performance of GRACE is added as a third calibration parameter. The relatively small spread of the resulting performance indices shows that the model produces consistent results for low/high discharges and GRACE values.

with increasing GRACE values, due to of accumulation of rainwater in the catchment areas. The drought period between 2007 and 2009 coincides with an overall decrease in water mass, while the water mass is more or less stable during the periods before and after the drought. The magnitude of the yearly variations in water mass follows the yearly rainfall trend and is therefore largest before 2007 and smallest during 2007-2009. The GRACE data after 2009 are more or less stable, with almost no difference in average water mass. This could indicate that a new equilibrium state is reached after the drought, where the outflow of the system is in balance with lower precipitation values.

The given GRACE values could also be influenced by leakage of mass over the borders of our study area, due to large soil water or groundwater mass variation just inside or outside our study area. But because the GRACE signal for a larger region, as given by Voss et al. (2013), is comparable to the signal we found, the effect of this mass leakage will be limited.

\subsection{Lakes and reservoirs}

To compare the total lake mass change with GRACE, all lake mass variations were added up and divided by the total area of the region. Figure 8 shows the surface water mass variation in terms of $\mathrm{EWH}$, with a $95 \%$ confidence interval. The total lake mass accounts for $75 \pm 3 \mathrm{~mm}$ of the water mass depletion between 2007 and 2009 and $55 \pm 6 \mathrm{~mm}$ 


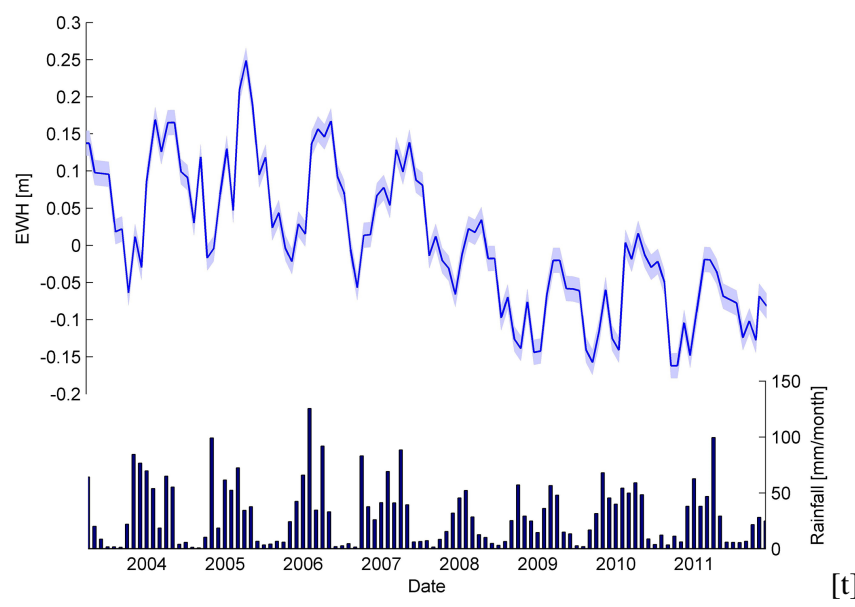

Figure 7. GRACE values and monthly precipitation for extended study area. During the wet winter periods, water accumulates in the region and total water mass increases. Largest water mass depletion occurred during seasons of 2007/2008 and 2008/2009.

of the yearly water mass variation during 2003-2011. This means that more than $50 \%$ of the total water mass depletion is caused by a decline of surface water mass. Such declines in surface water mass were already claimed for the whole Euphrates and Tigris basin by Longuevergne et al. (2013), but their values are higher than those given by Voss et al. (2013). The difference in results between our and other researches are likely caused by differences in the size of the studied basins, but exclusion of mostly smaller lakes can also play an important role. For example, lakes Hamrin, Adhaim, Dukan, Habbaniyah and Mosul had a total volume decline of about $13 \mathrm{~mm}$ EWH during the study period, but are not considered by Longuevergne et al. (2013) and Voss et al. (2013). Beside exclusion of several lakes, also mass leakage from lakes in the study area can lead to different results.

Figure 8 also shows that large lake mass variations are not uncommon in this region, which is due to large differences in rainfall from year to year and recurring droughts (Trigo et al., 2010). However, increasing water use in upstream countries like Turkey and Iran will hinder replenishment of lakes and reservoirs in northern Iraq (Ali, 2007; Beaumont, 1998).

\subsection{Modelled discharge of Dukan catchment}

Figure 9 shows the modelled and measured discharge at the inflow of Lake Dukan from 2005 to 2007. Generally, the low flows are captured quite well with discharge values within the given bands, while the modelled high flows deviate much more from the measured ones. This is likely related to fast and slow runoff mechanisms in the model, represented by the fast runoff and groundwater reservoirs respectively. The fast runoff reservoir is mainly fed by heavy or local rain events on short timescales, which are not well represented by the TRMM data. The slow runoff or groundwater reservoir has a

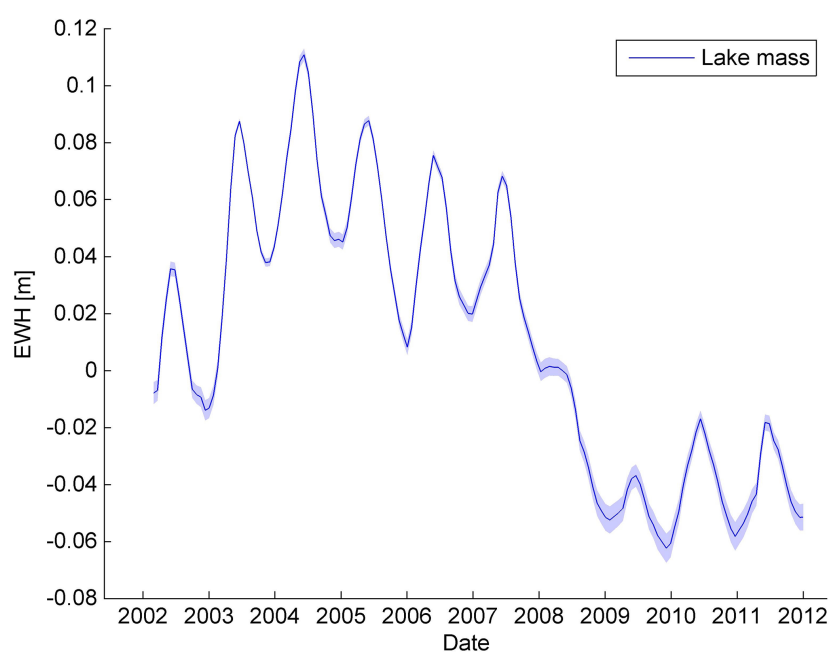

Figure 8. Lake mass variation.

much longer timescale and relies more on seasonal rainfall, which is captured much better by TRMM (Almazroui, 2011).

The modelled results are given as a Pareto ensemble based on the Pareto optimal solution for the NS and $\log$ NS performance indicators (Fig. 6). This ensemble is mainly a measure of the uncertainty of the model due to the model parameters. Uncertainty of the model due to forcings like rainfall or potential evaporation were not evaluated. Further, we assume a pristine catchment, but in reality the flows will be somewhat higher because of water use upstream. This mainly affects the baseflow and will result in higher groundwater variations. It is therefore more likely that we underestimate the water mass variation in the Dukan catchment.

\subsection{Natural groundwater variations}

The natural groundwater mass variation derived from the rainfall-runoff model is given in Fig. 10. This figure shows the optimal solution based on Eq. (6) together with the Pareto ensemble for the $\mathrm{NS}_{Q}$ and ${ }_{\log } \mathrm{NS}_{Q}$ performances and the Pareto ensemble based on the $\mathrm{NS}_{Q}, \log \mathrm{NS}_{Q}$ and $\mathrm{NS}_{M}$ performances. Note that the Pareto ensemble where GRACE mass is included also covers the other Pareto ensemble and includes both the red and the blue bands. Modelled groundwater variations from the $\mathrm{NS}_{Q}$ and $\log \mathrm{NS}_{Q}$ ensemble contribute $42 \pm 5 \mathrm{~mm}$ EWH to the yearly water mass variations and $26 \pm 8 \mathrm{~mm}$ EWH to the water mass depletion between 2007 and 2009. Modelled groundwater variations from the $\mathrm{NS}_{Q}, \log \mathrm{NS}_{Q}$ and $\mathrm{NS}_{M}$ ensemble contribute $49 \pm 7 \mathrm{~mm}$ EWH to the yearly water mass variations and $34 \pm 14 \mathrm{~mm}$ EWH to the water mass depletion between 2007 and 2009. This shows that modelled water mass depletion does increase when GRACE data are used as a calibration parameter, but model results are consistent.

The contribution of the natural groundwater mass explains why those values were not reproduced by the GLDAS model, 


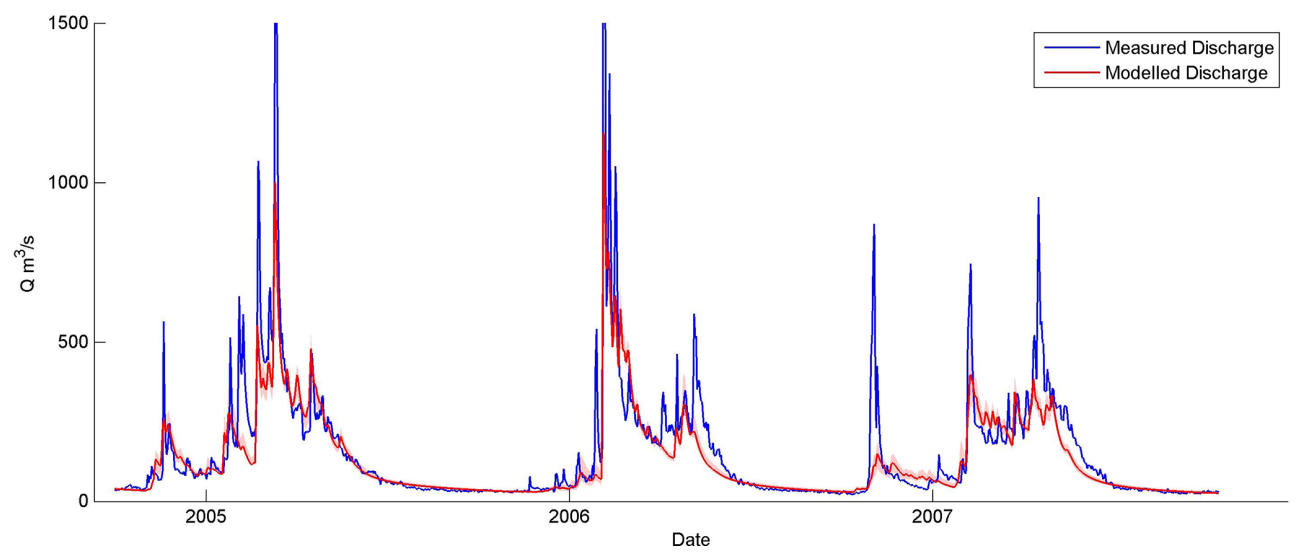

Figure 9. Discharge curves for the Dukan catchment between (October 2005 and October 2007). (left) Measured discharge in blue against modelled discharge in red. The red line gives the optimal solution and the bandwidth represents solutions within the Pareto ensemble. (right) Identical to left graph but here on a log scale, which gives a better view on the low flows during the dry season.

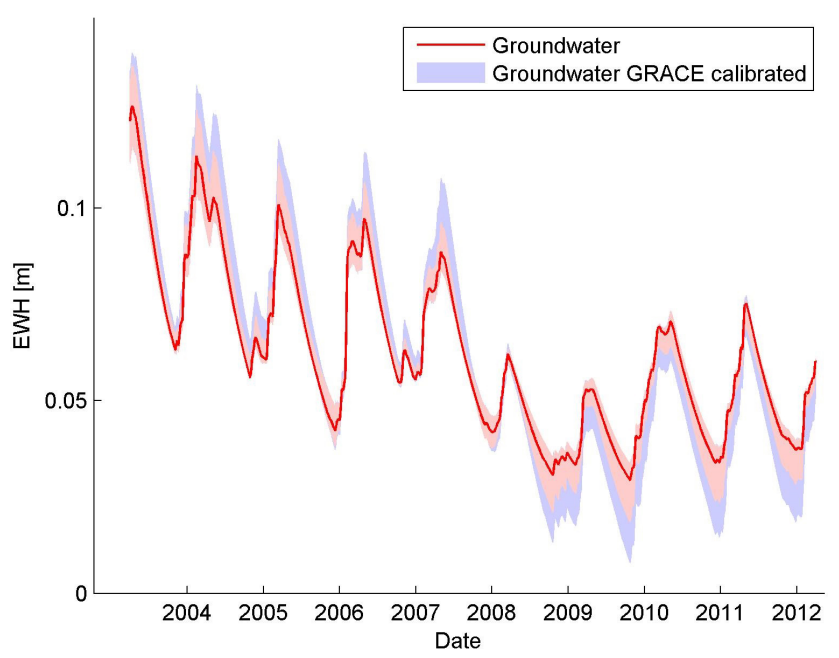

Figure 10. Water mass of groundwater reservoir smoothed over 10 days, showing a permanent decline of groundwater between 2007 and 2009. The red line and bandwidth represent the Pareto ensemble based on the NS and ${ }_{\log }$ NS of streamflow, while the blue bandwidth shows the extension of the Pareto ensemble when the NS for water mass is added as a third objective.

which does not include groundwater storage. The time series for the groundwater reservoir as given in Fig. 10 comprises a period with slowly decreasing groundwater levels up to 2007 , followed by a period with a strong groundwater depletion from 2007 to 2009, and a period with slowly increasing groundwater levels from 2010 to 2012. Groundwater from the karstified aquifers plays an important role in the groundwater depletion between 2007 and 2009, because of its high recharge during wet periods and fast discharge through springs during dry periods. While the aquifers still discharge water through springs during dry years, there is much less replenishment of the groundwater and groundwa- ter levels will drop. In the governorates of Sulaymaniyah and Duhok alone, about $1.5 \mathrm{~km}^{3}$ year $^{-1}$ water emerges every year from springs (Stevanovic and Markovic, 2004; UN-ESCWA and BGR, 2013). After 2009, modelled groundwater levels remained almost stable because rainfall rates were still below average, but a sequence of years with higher rainfall will result in a rise of groundwater levels and a revival of spring discharge.

To convert the groundwater mass variation from the Dukan area only to the whole of northern Iraq, the model was extended using the similarities between geological regions. This procedure is based on the identical geological background of these regions (Stevanovic et al., 2009). We do not know exactly whether the related aquifers developed in the same way, but because of the occurrence of springs in the region with similar characteristics we think this assumption can be made.

\subsection{Mass variations model reservoirs}

Beside the groundwater reservoir the model consists of three additional reservoirs to model the snow layer, unsaturated zone and fast runoff (Fig. 11). These reservoirs mainly contribute to the yearly mass variation of $122 \pm 7 \mathrm{~mm} \mathrm{EWH}$ and make only a small contribution to the water mass decline with $10 \pm 1 \mathrm{~mm}$ EWH. The unsaturated reservoirs show a recurring pattern every year whereby the soil layers get saturated during the wet season and dry out during the dry periods. The yearly variation of these reservoirs is $65 \pm 8 \mathrm{~mm}$ EWH. The fast runoff reservoir, which represents overland flow and interflow in the basin, shows peaks up to about $60 \mathrm{~mm}$ EWH during and shortly after intense rainfall events. The average yearly variation of the fast reservoir is $38 \pm 7 \mathrm{~mm}$ EWH and the decline after the drought is negligible. The snow reservoirs show the largest differences between dry and wet years, because of accumulating snow- 


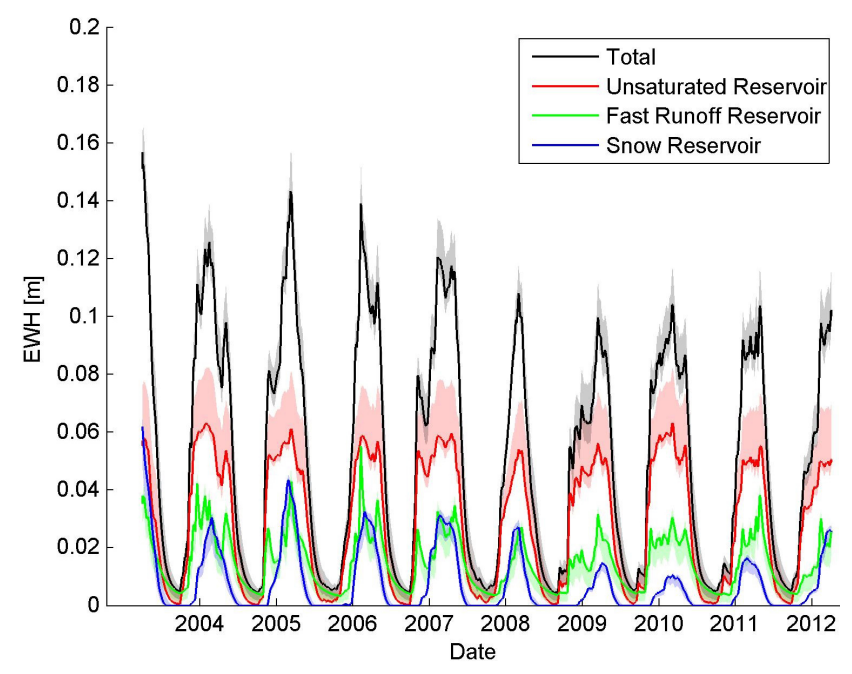

Figure 11. Water mass of the snow, unsaturated and fast runoff reservoir smoothed over 10 days. Lines represent the optimal model and the bandwidth the Pareto ensemble based on NS and $\log$ NS of streamflow.

fall during the whole rainy season. Still, almost all snow melts away during summer due to the strong temperature differences between seasons. The average yearly variation of the snow mass is $25 \pm 4 \mathrm{~mm}$ EWH and the average decline $6 \pm 1 \mathrm{~mm}$ EWH.

\subsection{GRACE and modelled values}

Figure 12 compares the total water mass variation from GRACE and the lakes plus the rainfall-runoff model. GRACE values indicate a mass depletion $146 \pm 6 \mathrm{~mm}$ EWH between 2007 and 2009 and a yearly mass variation of $286 \pm 24 \mathrm{~mm}$ EWH. The combined water mass variation of lakes and the rainfall-runoff model result in a water mass decline of $114 \pm 9 \mathrm{~mm}$ EWH and an average yearly variation of $225 \pm 9 \mathrm{~mm}$ EWH. The two graphs differ mainly in the winter and summer peaks, but also a part of the water mass decline remains unexplained.

Possible causes for the differences in yearly water mass variations are an underestimation of accumulated snow water or random errors in rainfall rates from TRMM data, which are $23 \%$ on average. Also the impact of anthropogenic activities can cause higher peaks. This can be due to surface water irrigation and groundwater use, which is replenished during the wet season. Other possible causes are additional water storage in depressions or water mass variability of smaller lakes. In theory, we could have changed the maximum storage of the unsaturated zone to fit the given curves better, but this would create a large difference between the modelled and the literature values.

Possible causes for the differences in mass decline are anthropogenic groundwater extraction or lakes, which were not included in the model. But also model uncertainties due to

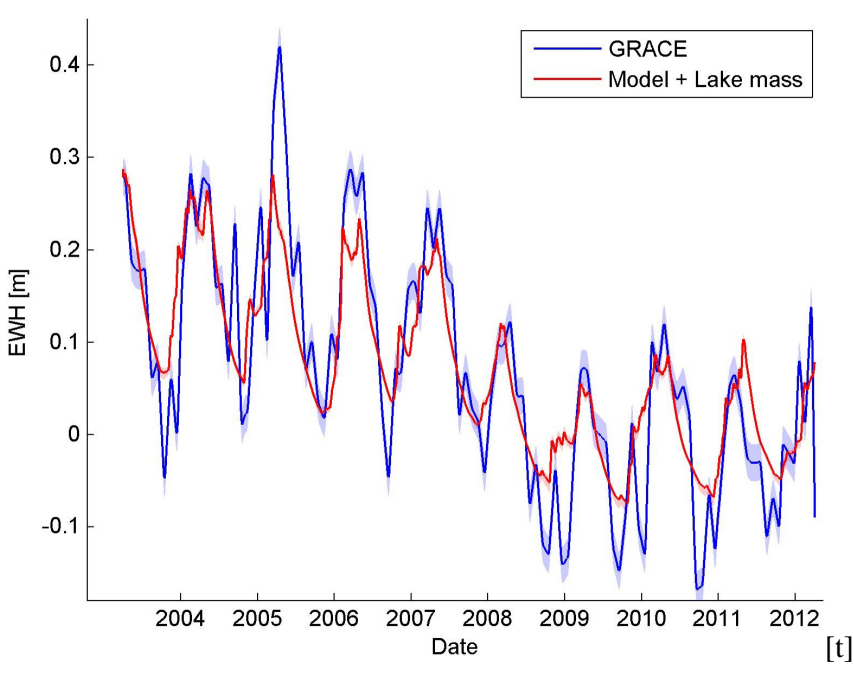

Figure 12. Comparison between resulting mass variation from GRACE and mass variation from lakes and the rainfall-runoff model.

mass leakage or the groundwater reservoirs can be a main cause.

\section{Conclusions}

\subsection{Water masses in northern Iraq}

The presented approach offers the possibility to quantify different hydrological processes in the region as well as the shares of surface water, soil moisture and groundwater in the total water mass variation. More importantly, the overall model shows that natural variation of groundwater, snow depth and soil moisture have a share of about $25 \%$ of the total water mass decline. With a depletion of $39 \pm 8 \mathrm{~mm}$ EWH it also explains more than half of the remaining mass decline if lake masses are extracted from GRACE results. This shows that natural groundwater variation has to be taken into account when GRACE mass values are used to determine overdraft of aquifers.

In particular, in the limestone aquifers of northern Iraq, strong groundwater variations are common due to extensive karst networks with high transmissivities and infiltration rates, feeding numerous springs in the region. Therefore, over-pumping of these aquifers is unlikely, as the groundwater table can vary strongly and the regional water supply is mainly supported by surface water. Additionally, almost all irrigation schemes in those areas are directly linked to large reservoirs.

The dependency of this region on surface water is also reflected by the large water mass variations of the surface water, which contributed about $75 \mathrm{~mm}$ out of $146 \mathrm{~mm}$ EWH observed by GRACE. With decreasing water availability and increasing water demands from riparian countries in the Tigris 
River catchment, the need for reliable water management tools and transboundary models is growing. The developed model helps to give insights into the available water resources and water flows between concerned countries. Contrary to other studies like Chenoweth et al. (2011), Kavvas et al. (2011) and Voss et al. (2013), main aquifers and water storages were modelled separately. Results are, therefore, more useful to water managers. Moreover, the model is based and calibrated on both satellite and in situ data, which enhances its reliability and predictive power.

\subsection{Model structure and input data}

This research has shown that GRACE can be an important data source in rainfall-runoff models because it gives direct measurements of the total water balance of a larger region. Especially in northern Iraq, where water resources and data on water resources are scarce, this is valuable information. However, it is not possible to determine what causes the water variations in these regions without additional data on precipitation, geology and river discharges. The data can partly be obtained from satellites, but the use of in situ data is still of vital importance. In our situation, there were only few data available, but they could be used for both model structure and calibration. Additionally, knowledge from local water experts and field observations gave important information on governing hydrological processes.

In our case, the rainfall and discharge stations covered only a part of the region, which resulted in increased model uncertainties. For example, the uncertainties in the total groundwater values are mainly caused by the alluvial groundwater reservoirs, which have only a small contribution to the total flow at Lake Dukan. Inclusion of discharge data series from other tributaries would reduce these uncertainties and give a better insight into the spatial variability of the region at the same time.

Acknowledgements. We would like to thank the staff members of the Geology Department at the University of Sulaimani for their assistance during our fieldwork. We also thank Adalbert Arsen and Jean-François Crétaux from LEGOS for the processing of altimetry data used in this paper.

Edited by: I. Neuweiler

\section{References}

Ali, M. H.: Transboundary waterways and streams along the IraqIran border lines... the reality and future, Tech. Rrep., Baghdad University, Baghdad, 2007.

Ali, S. S. and Stevanovic, Z.: Time Series Analysis of Saraw Springs - SE of Sulaimaniya, Iraqi Kurdistan Region, in: Advances in Research in Karst Media, edited by: Andreo, B., Carrasco, F., Durán, J. J., and LaMoreaux, J. W., 89-94, Springer, Leipzig, doi:10.1007/978-3-642-12486-0, 2010.
Ali, S. S., Stevanovic, Z., and Al-Jabbari, M. H.: Auto and Cross Correlation Analysis of Bestansur spring- Sharazoor Plain Iraqi Kurdistan Region, in: Proceeding of 3rd scientific conference of the College of Science, University of Baghdad, 1941-1948, 2009a.

Ali, S. S., Stevanovic, Z., and Jemcov, I.: The Mechanism and Influence on Karstic Spring Flow - Sachinar Spring Case Example, Sulaimaniya, NE Iraq, Iraqi Bull. Geol. Mining, 5, 87-100, $2009 b$.

Allen, R. G., Pereira, L. S., Raes, D., and Smith, M.: FAO Irrigation and Drainage Paper No. 56, Tech. Rep. 56, FAO, Rome, Italy, available at: http://www.fao.org/docrep/x0490e/x0490e00. htm (last access: 3 January 2015), 1998.

Al-Manmi, D. A. M. A.: Sirwan Transboundary River basin management, Tech. Rep., Stockholm, 2009.

Almazroui, M.: Calibration of TRMM rainfall climatology over Saudi Arabia during 1998-2009, Atmos. Res., 99, 400-414, doi:10.1016/j.atmosres.2010.11.006, 2011.

Altinbilek, H. D.: Water and Land Resources Development in Southeastern Turkey, Int. J. Water Resour. Develop., 13, 311332, doi:10.1080/07900629749719, 1997.

Altinbilek, D.: Development and management of the EuphratesTigris basin, Int. J. Water Resour. Develop., 20, 15-33, doi:10.1080/07900620310001635584, 2004.

Awange, J. L., Fleming, K. M., Kuhn, M., Featherstone, W. E., Heck, B., and Anjasmara, I.: On the suitability of the $4 \times 4$ degrees GRACE mascon solutions for remote sensing Australian hydrology, Remote Sens. Environ., 115, 864-875, doi:10.1016/j.rse.2010.11.014, 2011.

Beaumont, P.: Restructuring of Water Usage in the Tigris-Euphrates Basin: The Impact of Modern Water Management Policies, Middle East. Nat. Environ., 103, 168-186, 1998.

Brooks, D. B.: Between the Great Rivers: Water in the Heart of the Middle East, Int. J. Water Resour. Develop., 13, 291-310, doi:10.1080/07900629749700, 1997.

Chenoweth, J., Hadjinicolaou, P., Bruggeman, A., Lelieveld, J., Levin, Z., Lange, M. A., Xoplaki, E., and Hadjikakou, M.: Impact of climate change on the water resources of the eastern Mediterranean and Middle East region: Modeled 21st century changes and implications, Water Resour. Res., 47, W06506, doi:10.1029/2010WR010269, 2011.

Crétaux, J.-F., Jelinski, W., Calmant, S., Kouraev, A., Vuglinski, V., Bergé-Nguyen, M., Gennero, M.-C., Nino, F., Abarca Del Rio, R., Cazenave, A., and Maisongrande, P.: SOLS: A lake database to monitor in the Near Real Time water level and storage variations from remote sensing data, Adv. Space Res., 47, 1497-1507, doi:10.1016/j.asr.2011.01.004, 2011.

Fadhil, A. M.: Drought mapping using Geoinformation technology for some sites in the Iraqi Kurdistan region, Int. J. Digital Earth, 4, 239-257, doi:10.1080/17538947.2010.489971, 2011.

Fenicia, F., Kavetski, D., and Savenije, H. H. G.: Elements of a flexible approach for conceptual hydrological modeling: 1. Motivation and theoretical development, Water Resour. Res., 47, W11510, doi:10.1029/2010WR010174, 2011.

Gibelin, A. and Déqué, M.: Anthropogenic climate change over the Mediterranean region simulated by a global variable resolution model, Clim. Dynam., 20, 327-339, doi:10.1007/s00382-0020277-1, 2003. 
Giorgi, F. and Lionello, P.: Climate change projections for the Mediterranean region, Global Planet. Change, 63, 90-104, doi:10.1016/j.gloplacha.2007.09.005, 2008.

Hinderer, J., Andersen, O., Lemoine, F., Crossley, D., and Boy, J.-P.: Seasonal changes in the European gravity field from GRACE: A comparison with superconducting gravimeters and hydrology model predictions, J. Geodynam., 41, 59-68, doi:10.1016/j.jog.2005.08.037, 2006.

Huffman, G. J., Bolvin, D. T., Nelkin, E. J., Wolff, D. B., Adler, R. F., Gu, G., Hong, Y., Bowman, K. P., and Stocker, E. F.: The TRMM Multisatellite Precipitation Analysis (TMPA): Quasi-Global, Multiyear, Combined-Sensor Precipitation Estimates at Fine Scales, J. Hydrometeorol., 8, 38-55, doi:10.1175/JHM560.1, 2007.

Issa, I. E., Al-Ansari, N., and Knutsson, S.: Sedimentation and new operational curves for Mosul Dam, Iraq, Hydrol. Sci. J., 58, 1456-1466, doi:10.1080/02626667.2013.789138, 2013.

Kavvas, M., Chen, Z., Anderson, M., Ohara, N., Yoon, J., and Xiang, F.: A study of water balances over the Tigris-Euphrates watershed, Phys. Chem. Earth, Parts A/B/C, 36, 197-203, doi:10.1016/j.pce.2010.02.005, 2011.

Krásný, J., Alsam, S., and Jassim, S. Z.: Hydrogeology, in: Geology of Iraq, edited by: Jassim, S. Z. and Goff, J. C., 251-287, Publishers Dolin, Prague, 1st Edn., 2006.

Krogh, P. E., Andersen, O. B., Michailovsky, C. I. B., BauerGottwein, P., Rowlands, D. D., Luthcke, S. B., and Chinn, D. S.: Evaluating terrestrial water storage variations from regionally constrained GRACE mascon data and hydrological models over Southern Africa - preliminary results, Int. J. Remote Sens., 31, 3899-3912, doi:10.1080/01431161.2010.483483, 2010.

Lindström, G., Johansson, B., and Persson, M.: Development and test of the distributed HBV-96 hydrological model, J. Hydrol., 201, 272-288, 1997.

Longuevergne, L., Wilson, C. R., Scanlon, B. R., and Crétaux, J. F.: GRACE water storage estimates for the Middle East and other regions with significant reservoir and lake storage, Hydrol. Earth Syst. Sci., 17, 4817-4830, doi:10.5194/hess-17-48172013, 2013.

Mariotti, A., Zeng, N., Yoon, J.-H., Artale, V., Navarra, A., Alpert, P., and Li, L. Z. X.: Mediterranean water cycle changes: transition to drier 21st century conditions in observations and CMIP3 simulations, Environ. Res. Lett., 3, 044001, doi:10.1088/17489326/3/4/044001, 2008.

McLeman, R. A.: Settlement abandonment in the context of global environmental change, Global Environ. Change, 21, S108-S120, doi:10.1016/j.gloenvcha.2011.08.004, 2011.

Michel, D., Pandya, A., Hasnain, S. I., Sticklor, R., and Panuganti, S.: Water Challenges and Cooperative Response in the Middle East and North Africa, in: U.S.-Islamic World Forum, 11-15, US World Forum Papers, available at: http://www.brookings.edu/ /media/Research/Files/Papers/ 2012/1\%1/iwfpapers/Waterweb.pdf, 2012.

Ngo-Duc, T., Laval, K., Ramillien, G., Polcher, J., and Cazenave, A.: Validation of the land water storage simulated by Organising Carbon and Hydrology in Dynamic Ecosystems (ORCHIDEE) with Gravity Recovery and Climate Experiment (GRACE) data, Water Resour. Res., 43, W04427, doi:10.1029/2006WR004941, 2007.
Rodell, M., Houser, P. R., Jambor, U., Gottschalck, J., Mitchell, K., Meng, C.-J., Arsenault, K., Cosgrove, B., Radakovich, J., Bosilovich, M., Entin*, J. K., Walker, J. P., Lohmann, D., and Toll, D.: The Global Land Data Assimilation System, B. Am. Meteorol. Soc., 85, 381-394, doi:10.1175/BAMS-85-3-381, 2004.

Savenije, H. H. G.: HESS opinions “Topography driven conceptual modelling (FLEX-Topo)", Hydrol. Earth Syst. Sci., 14, 26812692, doi:10.5194/hess-14-2681-2010, 2010.

Schmidt, R., Petrovic, S., Güntner, A., Barthelmes, F., Wünsch, J., and Kusche, J.: Periodic components of water storage changes from GRACE and global hydrology models, J. Geophys. Res., 113, B08419, doi:10.1029/2007JB005363, 2008.

Schrama, E. J. O. and Wouters, B.: Revisiting Greenland ice sheet mass loss observed by GRACE, J. Geophys. Res., 116, B02407, doi:10.1029/2009JB006847, 2011.

Schrama, E. J. O., Wouters, B., and Lavallée, D. A.: Signal and noise in Gravity Recovery and Climate Experiment (GRACE) observed surface mass variations, J. Geophys. Res., 112, B08407, doi:10.1029/2006JB004882, 2007.

Schrama, E. J., Wouters, B., and Rietbroek, R.: A mascon approach to assess ice sheet and glacier mass balances and their uncertainties from GRACE data, J. Geophys. Res.-Solid Earth, 119, 6048-6066, doi:10.1002/2013JB010923, 2014.

Shepherd, A., Ivins, E. R., A, G., Barletta, V. R., Bentley, M. J., Bettadpur, S., Briggs, K. H., Bromwich, D. H., Forsberg, R., Galin, N., Horwath, M., Jacobs, S., Joughin, I., King, M. a., Lenaerts, J. T. M., Li, J., Ligtenberg, S. R. M., Luckman, A., Luthcke, S. B., McMillan, M., Meister, R., Milne, G., Mouginot, J., Muir, A., Nicolas, J. P., Paden, J., Payne, A. J., Pritchard, H., Rignot, E., Rott, H., Sø rensen, L. S., Scambos, T. a., Scheuchl, B., Schrama, E. J. O., Smith, B., Sundal, A. V., van Angelen, J. H., van de Berg, W. J., van den Broeke, M. R., Vaughan, D. G., Velicogna, I., Wahr, J., Whitehouse, P. L., Wingham, D. J., Yi, D., Young, D., and Zwally, H. J.: A reconciled estimate of icesheet mass balance, Science (New York, N.Y.), 338, 1183-1189, doi:10.1126/science.1228102, 2012.

Stevanovic, Z. and Iurkiewicz, A.: Groundwater management in northern Iraq, Hydrogeol. J., 17, 367-378, doi:10.1007/s10040008-0331-0, 2008.

Stevanovic, Z. and Markovic, M.: Hydrogeology of Northern Iraq, Food and Agriculture Organisation of the United Nations, Rome, 2004.

Stevanovic, Z., Iurkiewicz, A., and Maran, A.: New Insights Into Karst and Caves of Northwestern Zagros Northern Iraq, Acta carsologica, 38, 83-96, doi:10.1007/978-3-642-12486-0, 2009.

Swenson, S. and Wahr, J.: Post-processing removal of correlated errors in GRACE data, Geophys. Res. Lett., 33, L08402, doi:10.1029/2005GL025285, 2006.

Syed, T. H., Famiglietti, J. S., Rodell, M., Chen, J., and Wilson, C. R.: Analysis of terrestrial water storage changes from GRACE and GLDAS, Water Resour. Res., 44, W02433, doi:10.1029/2006WR005779, 2008.

Tourian, M., Elmi, O., Chen, Q., Devaraju, B., Roohi, S., and Sneeuw, N.: A spaceborne multisensor approach to monitor the desiccation of Lake Urmia in Iran, Remote Sens. Environ., 156, 349-360, doi:10.1016/j.rse.2014.10.006, 2015.

Trigo, R. M., Gouveia, C. M., and Barriopedro, D.: The intense 2007-2009 drought in the Fertile Crescent: Impacts and associ- 
ated atmospheric circulation, Agr. Forest Meteorol., 150, 12451257, doi:10.1016/j.agrformet.2010.05.006, 2010.

UN-ESCWA and BGR: Inventory of Shared Water Resources in Western Asia, Tech. Rep., United Nations Economic ans Social Commission for Western Asia; Bundesanstalt für Geowissenschaften und Rohstoffe, Beirut, available at: http:// waterinventory.org/ (last access: 28 August 2014), 2013.

USDA/FAS: Global Reservoirs and Lake Monitor, available at: http://www.pecad.fas.usda.gov/cropexplorer/global_reservoir (last access: 8 January 2015), 2013.
Voss, K. A., Famiglietti, J. S., Lo, M., Linage, C., Rodell, M., and Swenson, S. C.: Groundwater depletion in the Middle East from GRACE with implications for transboundary water management in the Tigris-Euphrates-Western Iran region., Water Resour. Rres., 49, 904-914, doi:10.1002/wrcr.20078, 2013.

Werth, S., Güntner, A., Petrovic, S., and Schmidt, R.: Integration of GRACE mass variations into a global hydrological model, Earth Planet. Sci. Lett., 277, 166-173, doi:10.1016/j.epsl.2008.10.021, 2009. 